\title{
The Gellular Response of the Weanling Rat Thymus Gland to Undernutrition and Rehabilitation
}

\author{
P. A. McAnulty ${ }^{[33]}$ and J. W. T. Dickerson \\ Department of Growth and Development, Institute of Child Health, London, and Department of Biochemistry, University of \\ Surrey, Guildford, Surrey, England
}

\begin{abstract}
Extract
Weanling male black-hooded rats were maintained at practically constant body weight between 24 and 52 days of age by giving them reduced amounts of their normal diet. Ten animals were then killed at $0,3,7,10$, and 16 days of rehabilitation on an ad libitum diet. At each age of rehabilitation, 10 control animals of the same age, and a similar number of the same body weight, were also killed. The thymuses of the animals were assayed for DNA (a measure of cell number), RNA, and protein, and the protein/DNA ratio was calculated (a measure of cell size). The thymus glands were also examined histologically.

The thymus lost $81 \%$ of its initial weight during undernutrition, but on rehabilitation returned to a normal weight relative to body weight within 10 days, and to a normal weight for age within 16 days. Thereafter it remained of normal weight. The absolute amounts of DNA and RNA responded in a way similar to weight. The absolute amount of protein also decreased during undernutrition, but on rehabilitation showed a poor response during the first 3 days, then increased rapidly to return to normal within 10 days. The protein/DNA ratio showed a sevenfold increase during undernutrition, but returned to normal within 7 days. Thus, atrophy of the thymus during undernutrition was due to a great loss of small cells, which left a population of large cells in the remnant; this was confirmed in histologic sections. However, the thymus had a remarkable capacity for recovery, and the body weight was more important than age as an influence on the rate of recovery.
\end{abstract}

\section{Speculation}

The loss of cells from the thymus during undernutrition may be one of the causes of increased susceptibility to infection in malnourished children and animals, but it is necessary to ascertain whether those cells which are lost from the thymus are immunologically active, and also to investigate whether the return to a normal cell population on rehabilitation is accompanied by a return to normal immunologic function. This work is in hand.

\section{Introduction}

Marked atrophy of the thymus occurs during malnutrition in animals [6] and man [28]. The "nutritional thymectomy" [26] that occurs in kwashiorkor so depletes the thymus that almost all that remains is the connective tissue. Malnutrition also results in reduction in the size of the tonsils and the peripheral lym- 
phatic tissue. Furthermore, there is a failure to reject skin grafts, and, although plasma immunoglobulins are not depressed, the levels of complement are reduced [26]. Lymphocyte transformation rates, after stimulation with phytohemagglutinin, are also reduced in children with protein-calorie malnutrition $[5,23]$.

Smythe and Camplell [25] reported that protein-calorie malnutrition results in a characteristic pattern of infection with symptoms that are typical of conditions in which cell-mediated immunity is abnormal. Studies in marasmic pigs [11] and in mice and rats fed protein-deficient diets $[7,14]$, have shown that both cellular and humoral immunity are depressed. It seems probable that these defects result from the effects of malnutrition on the thymolymphatic system [26].

The cell population of the thymus is characterized by a rapid turnover of cells $[8,9]$, and tissues of this type are particularly vulnerable to periods of malnutrition [29].

The present study was undertaken to cletermine the cellular events accompanying thymic atrophy induced by a period of caloric restriction, and to investigate the events during early rehabilitation.

\section{Materials and Methods}

Black-hooded rats of Medical Research Council stock were raiscd in litters of eight and weaned at 21 days of age on a stock diet [30] which contained $20 \%$ protein, $0.88 \mathrm{mg}$ folic acid $/ \mathrm{kg}, 8.60 \mathrm{mg}$ pyricloxine $/ \mathrm{kg}$, and adequate amounts of the other vitamins and minerals. At 24 days of age, 150 males which weighed $46-51 \mathrm{~g}$ were caged individually and allocated to 1 of 15 groups. Five groups were "experimental," and the food intake of these animals was so restricted for 28 days that there was no significant increase in body weight. After 28 days of undernutrition, one group was killed without rehabilitation, and the remaining four groups were rehabilitated on the stock diet for $3,7,10$, and 16 days, respectively. Five of the remaining groups of animals were killed at the same age as the experimental animals, and the remaining five at the same body weights. Ten animals in each group were used for chemical analysis, and two for histologic examination.

The rats were killed with chloroform, and the thymus dissected out rapidly and weighed. Glands for chemical analysis were frozen immediately on Dry Ice and stored at $-15^{\circ}$; those for histology were fixed in formal saline and blocked in paraffin wax.

DNA and RNA were extracted from homogenates of thymic tissue as described by Munro and Fleck [19].
DNA was determined by the diphenylamine reaction [3], and RNA by ultraviolet absorption [19]. Soluble protein was extracted with $0.1 \mathrm{~N}$ sodium hydroxide solution and determined by the method of Lowry et al. [12].

Histologic sections were stained with Ehrlich's hematoxylin and eosin.

\section{Results}

Between 24 and 52 days of age, the body wcights of the normal animals rose $147 \mathrm{~g}$ and those of the experimental animals, only $1.8 \mathrm{~g}$. During the subsequent 16 days of rehabilitation the body weights of the experimental animals rose by $110 \mathrm{~g}$, whereas those of the controls rose by a further $83 \mathrm{~g}$.

In the normal animals, thymus weight (Fig. 1) increased steadily between 24 and 55 days of age, with no further significant change up to 68 days. During the period of undernutrition, thymus weight fell by $81 \%$ of its initial weight. On rehabilitation the weight rose rapidly, and after 16 days of rehabilitation it did not differ significantly from that of normal animals of the same age. The ratio of thymus to body weight steadily declined with age in the normal animals, and it did so at a faster rate in the undernourished animals (Fig. 2). On rehabilitation, the thymus/body weight ratio increased, and reached a normal value for the age of the animal after 7 days; after 16 days it was greater than in the controls of the same age. When compared with normal animals of the same body weight (Fig. 3), the thymus/body weight ratio returned to normal alter 10 days and followed the normal curve to 16 days. A further two groups of 10 undernourished animals were found to continue this normal relation during a longer period of rehabilitation.

In normal animals the absolute amount of DNA (Fig. 4) increased up to 62 clays of age, but between 47 and 62 days the increase was not statistically significant. The concentration of DNA (Fig. 5) showed little variation during the period investigated, although there was a transient but significant decrease between 4.7 and 52 days of age. In the experimental animals the absolute amount of DNA fell rapidly (Fig. 4), and on rehabilitation increased at a rate such that after 16 days of rehabilitation, the absolute amount of DNA was normal for the age of the animals. For the body weight of the animal, however, the absolute amount of DNA was normal after 10 days of rehabilitation, and was above normal by 16 days. The concentration of DNA (Fig. 5) fell significantly during undernutrition 


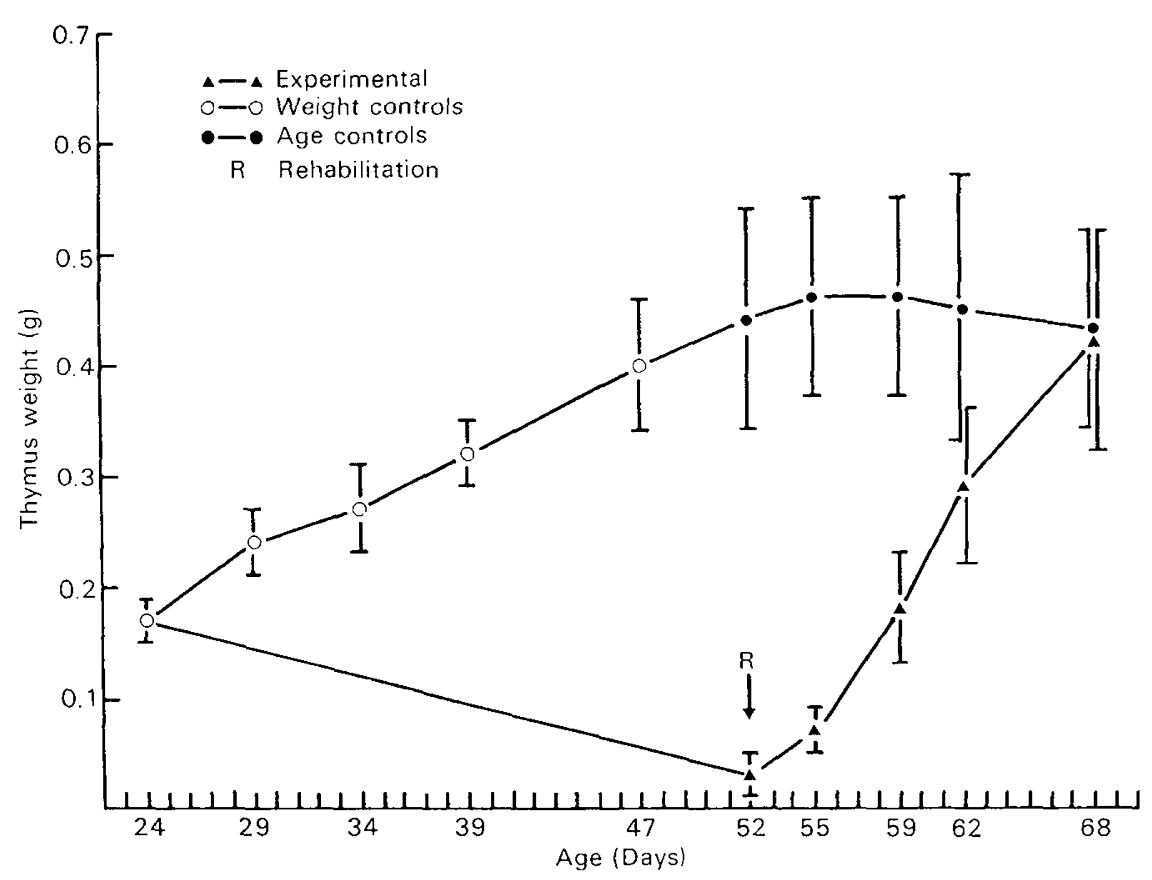

Fig. 1. Thymus weight of the rat during normal development, undernutrition, and rehabilitation. SD ( \pm 1 ) is indicated.

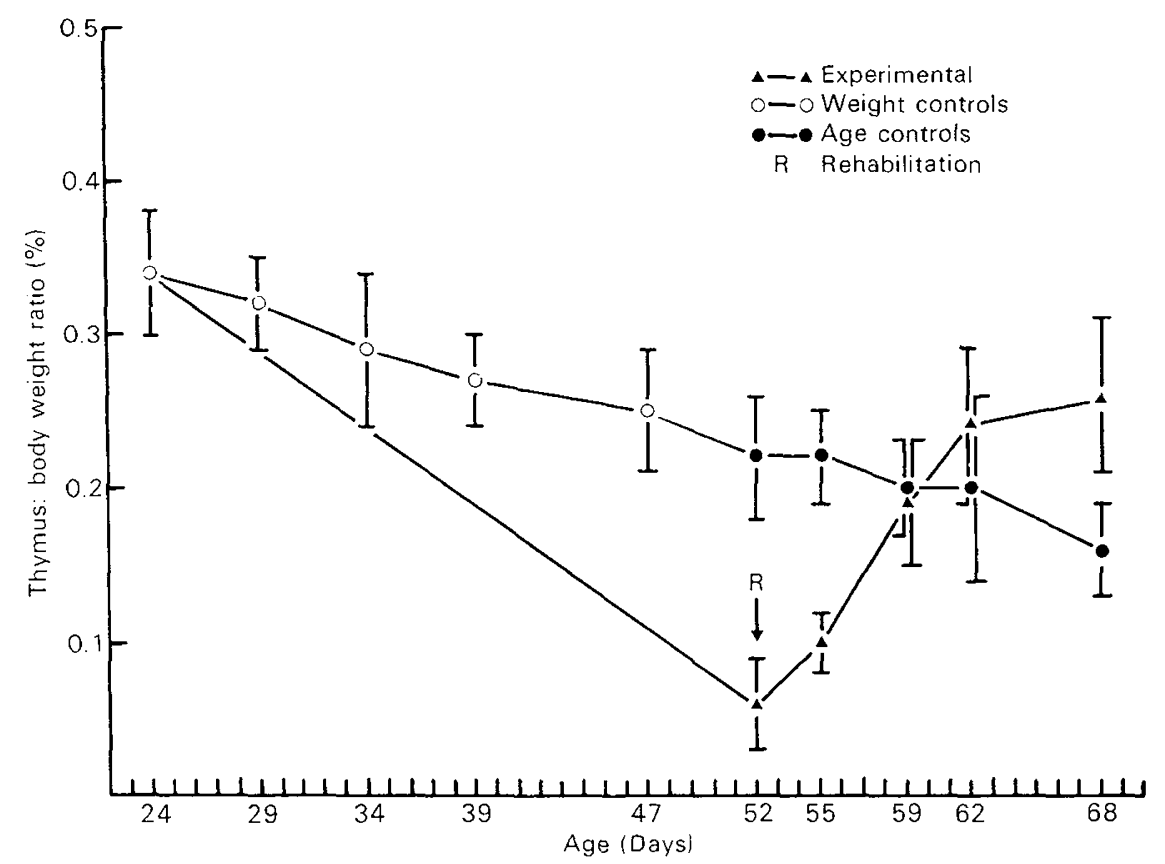

Fig. 2. Thymus to body weight ratio of the rat during normal development, undernutrition, and rehabilitation, plotted against age. SD $( \pm 1)$ is indicated.

and on rehabilitation had returned to normal by 7 days.

The absolute amount of RNA in the thymus gland of the control and experimental animals followed a similar course to that of DNA, whereas the concentra- tion of RNA remained practically constant throughout the experiment in both the control and experimental animals. The absolute amount of protein increased up to 55 days of age in the normal animals, with no change thereafter. There was no change in protein 


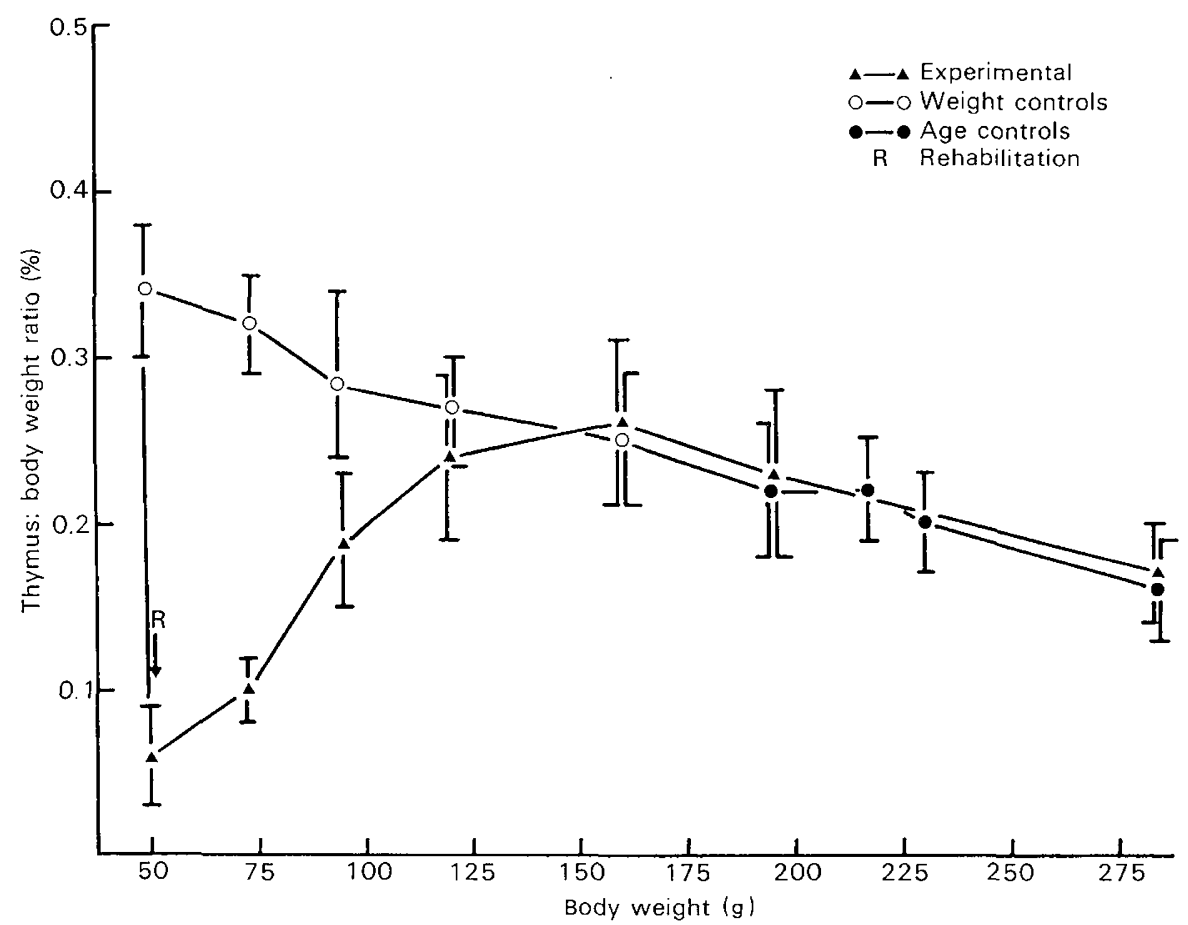

Fig. 3. Thymus to body weight ratio of the rat during normal development, undernutrition, and rehabilitation, plotted against body weight. SD $( \pm 1)$ is indicated.

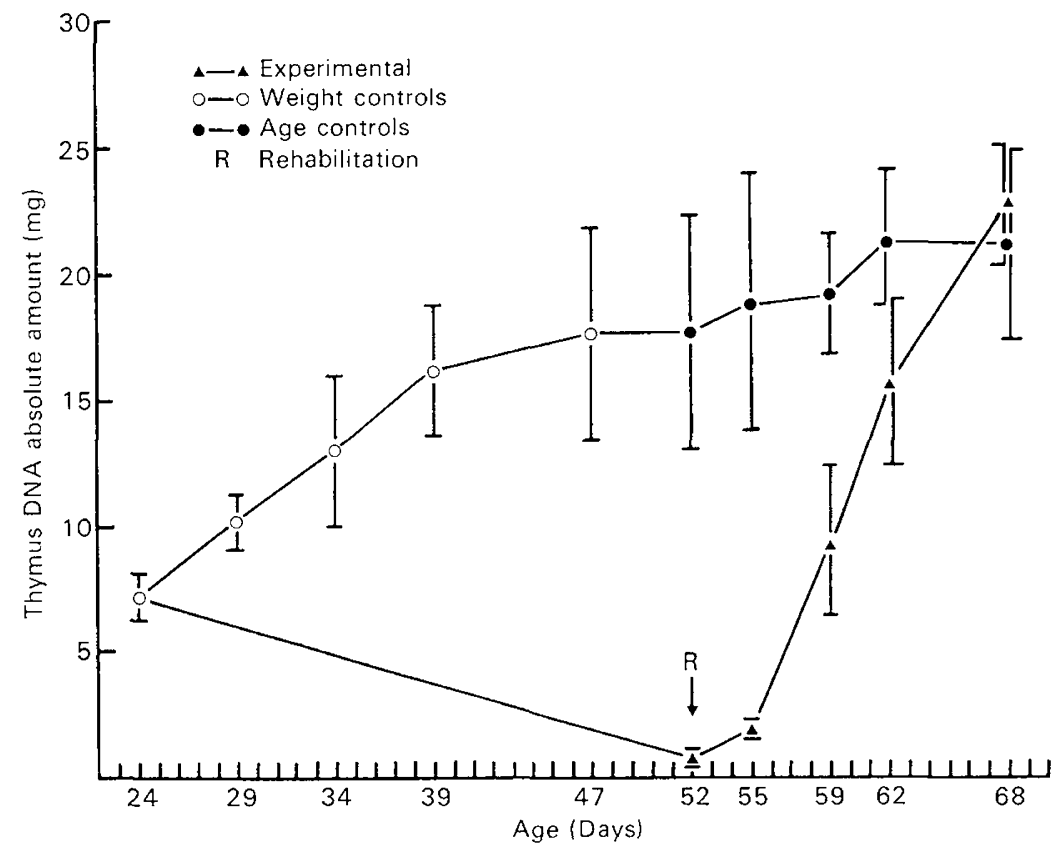

Fig. 4. Absolute amount of rat thymic DNA during normal development, undernutrition, and rehabilitation. SD ( \pm 1 ) is indicated.

concentration in normal animals over the period investigated. During undernutrition the absolute amount of protein fell, and during the first 3 days of rehabilitation, there was no significant change in the amount.
Thereafter the absolute amount of protein increased rapidly, and reached a normal value for the age of the animal after 10 days of rehabilitation. Protein concentration increased significantly during undernutrition, 


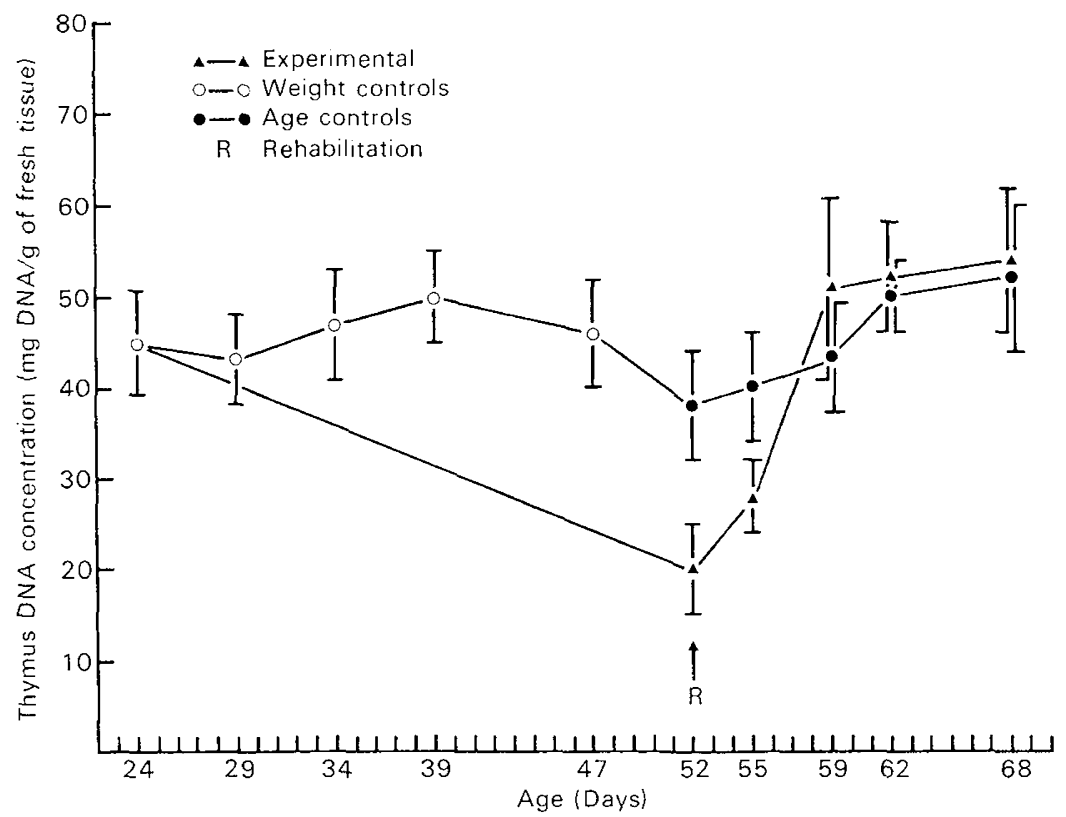

Fig. 5. Concentration of rat thymic DNA during normal development, undernutrition, and rehabilitation. SD $( \pm 1)$ is indicatcd.

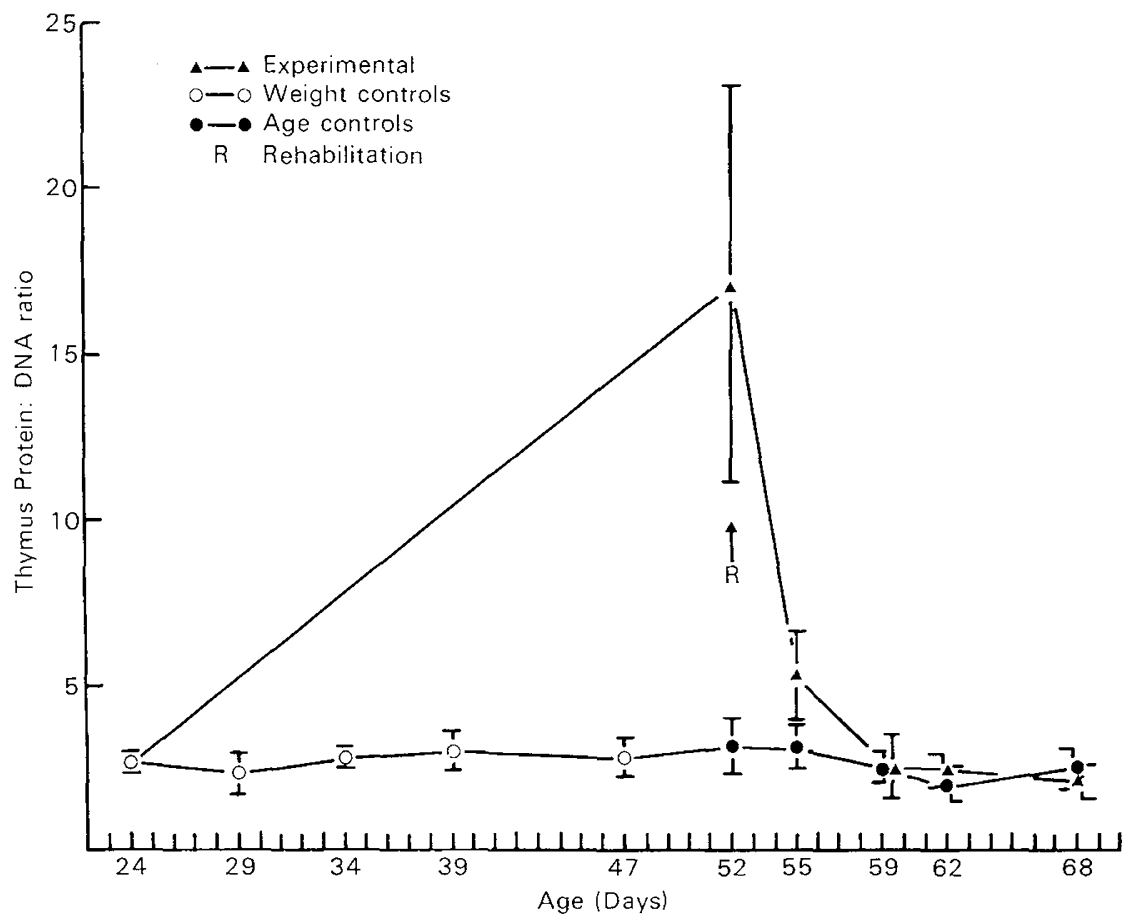

Fig. 6. Protein/DNA ratio of the rat thymus during normal development, undernutrition, and rehabilitation. $s \mathrm{D}( \pm 1)$ is indicated.

and upon rehabilitation decreased, to return to normal within 7 days.

The protein/DNA ratio (Fig. 6), a measure of cell size, showed only slight variations during normal growth, but increased greatly during undernutrition, and subsequently decreased rapidly during rehabilitation to return to normal within 7 days.

Histologically, the thymic lobes of the undernourished animals were smaller than those of well nourished animals of the same body weight, and the demar- 

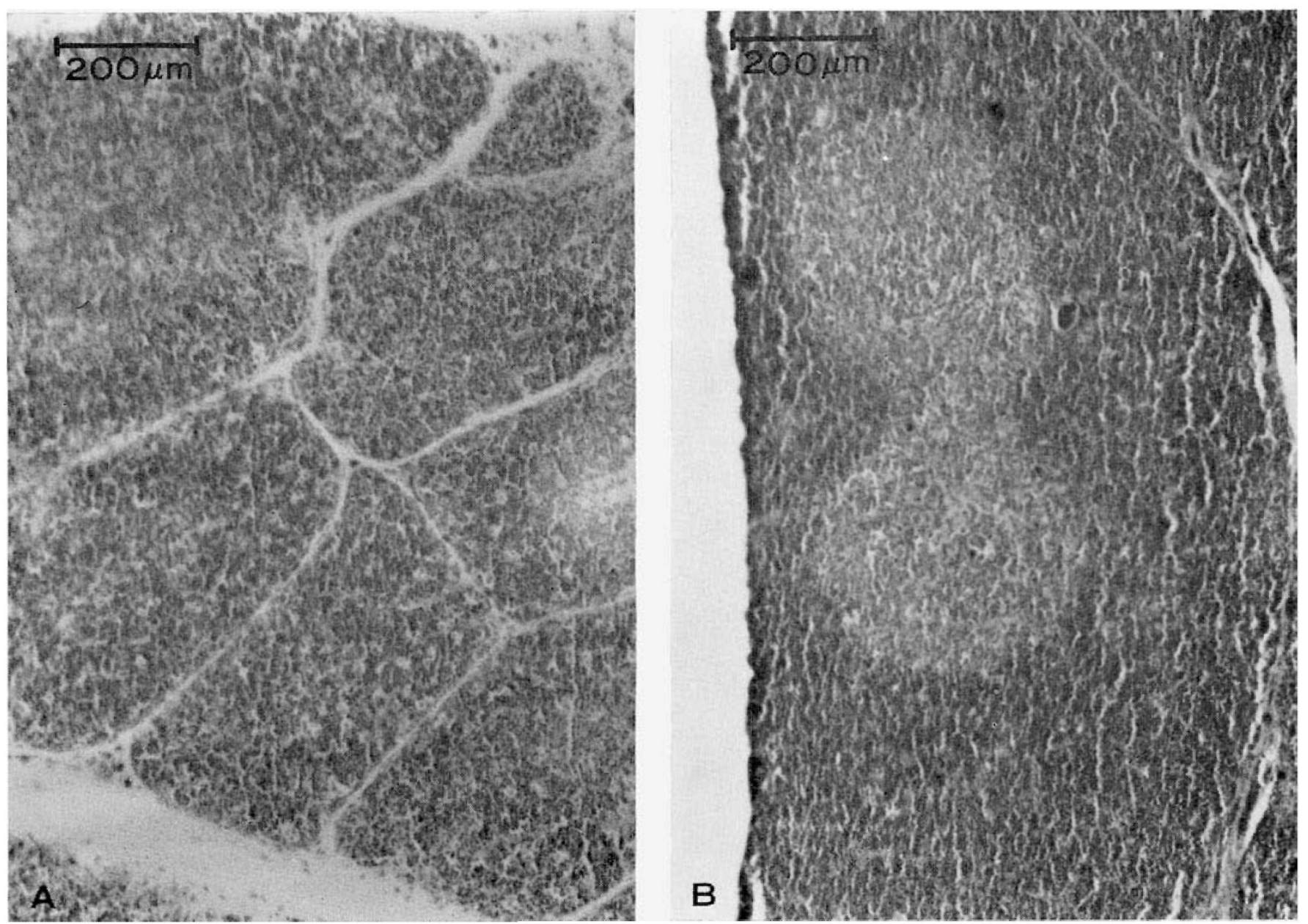

Fig. 7. A: The histologic appearance of the thymus of a rat undernourished for 28 days; $B$ : the histologic appearance of the thymus of a normal rat of the same body weight.

cation between cortex and medulla was less distinct (Fig. 7). The number of lymphocytes per field was much smaller, and hence the number of large cells much greater.

\section{Discussion}

The normal thymus gland of children and young animals contains a very large number of small lymphocytes, together with a smaller number of large cells, which include prolymphocytes, lymphoblasts, and epithelial cells [21, 22]. In the present study, atrophy of the thymus occurred in the weanling rat maintained at constant body weight by undernutrition for 4 weeks. This atrophy was accompanied by a large fall in the number of cells, as judged by changes in the amount of DNA, and there was also an increase in the mean cell size, as judged by the protein/DNA ratio. Histo- logic examination suggested that small lymphocytes had been lost from the tissue, and this resulted in the disappearance of the normal clear differentiation between cortex and medulla. This differentiation disappears completely in both rats [18] and children [17] who are severely deprived nutritionally.

It seems that most cell division in the thymus of children and young animals is arrested by undernutrition, and the existing small lymphocytes lost, presumably by the normal mechanism of pyknosis within the thymus and some migration into the blood stream [16]. In folate and vitamin $\mathrm{B}_{12}$ deficiencies, a reduced lymphocyte transformation rate has been reported, and it has been suggested that this was due to an arrest of DNA synthesis [15]. The arrest may be due purely to the nutrient deficit, but it may also be due to elevated corticosteroid secretion $[11,17]$ which occurs in undernourished animals and children $[1,2,10]$. Corti- 
costeroids have been shown to cause thymic involution [24]. However, it has been pointed out that if elevated corticosteroid levels are the cause of the arrest of cell division, it is inconsistent that thymic atrophy is greater in kwashiorkor than in marasmus [26], as plasma cortisol levels are higher in marasmus than in kwashiorkor [20].

The thymus grew very rapidly upon rehabilitation until it reached the correct ratio to the body weight, irrespective of age, inasmuch as the animals were still retarded in weight for their age. The thymus then maintained the correct ratio. Thus, there seems to be a functional demand of the body upon the thymus which dictates an optimal thymic weight for maximum effectiveness, or alternatively, the body is incapable of maintaining a thymus above a certain size. This situation is in contrast to the spleen, which, after a period of undernutrition, shows the same rapid weight increase, but becomes hypertrophied, being relatively too large for the weight or age of the animal [13].

The rapid increase in weight of the thymus upon rehabilitation was accompanied by immediate increases in RNA and DNA, but there was an apparent lag in the response of protein synthesis. This suggests that during the first 3 days a greater proportion of small cells were being formed, and this is reflected in the sharp drop in the protein/DNA ratio.

After 16 days the thymus had returned to normal with respect to weight, cell number, and cell size, and this was in contrast to the liver and skeletal muscles of the same animals, which were still retarded at this stage of rehabilitation [13]. Furthermore, in rats subjected to similar growth restrictions as the result of feeding of low protein diets, thymus weight shows the same powers of recovery [27], but brain weight, quadriceps muscle weight, and dimensions of certain bones do not return to normal after rehabilitation for 88 days [4].

It has been suggested that the changes in the cell population of the thymus during undernutrition play an important role in the increased susceptibility to infection in undernourished children. The present results indicate that, at least in the growing rat, these effects on the cell population of the thymus may be rapidly reversed by adequate rehabilitation, but whether this is accompanied by a return to normal immunologic functioning needs to be elucidated.

\section{Summary}

The development of the thymus gland was studied in male weanling rats undernourished from 24 to 52 days after birth, and subsequently rehabilitated for varying periods of time up to 16 days, in an attempt to clarify the mechanisms underlying the increased susceptibility to infections of children suffering from protein-calorie malnutrition. The DNA content was used as a measure of cell number, the ratio of protein/DNA was used as a measure of cell size, and RNA was also determined. During undernutrition, body weight remained constant, but the weight of the thymus fell due to a large decrease in the number of cells. The mean cell size increased. These changes are interpreted in the light of histologic findings as being due to a great loss of small lymphocytes, which left a greater than normal concentration of large cells. On rehabilitation, the thymus rapidly increased in weight, so that after 7 days it became normal for the body weight of the animal; thereafter this correct ratio was maintained. During the first 3 days of rehabilitation the cell number increased with very little change in total protein, but in the subsequent 4 days, protein was added to the gland. Cell number, cell size, and levels of RNA all returned to normal within 16 days of rehabilitation.

\section{References and Notes}

1. Adlard, B. P. F., ANd Smart, J. L.: Adrenocortical function in rats subjected to mutritional deprivation in early life. $J$. Endocrinol., 54: 99 (1972).

2. Alleyne, G. A. O., AND Young, V. H.: Adrenocortical function in children with severe protein-calorie malnutrition. Clin. Sci., 33: 189 (1967).

3. Burton, K.: A study of the conditions and mechanism of the diphenylamine reaction for the colorimetric estimation of deoxyribonucleic acid. Biochem. J., 62: 315 (1956).

4. Digkerson, J. W. T., Hughes, P. C. R., and McAnulty, P. A.: The growth and development of rats fed a low protein diet. Brit. J. Nutr., 27: 527 (1972).

5. Grace, H. J., Armstrong, D., and Smythe, P. M.: Reduced lymphocyte transformation in protein caloric malnutrition. S. Afr. Med. J., 46: 402 (1972).

6. JAckson, C. M.: The effects of inanition and malnutrition upon growth and structure. (Blakiston, Philadelphia, 1925).

7. Jose, D. G., Stutman, O., ANd Good, R. A.: Long term effects on immune function of early nutritional deprivation. Nature, 241: 57 (1973).

8. Leblond, C. P.: Classification of cell populations on the basis of their proliferative behavior. Nat. Cancer Inst. Monogr., 14: 119 (1964).

9. Leblond, C. P., and Walker, B. E.: Renewal of cell populations. Physiol. Rev., 36: 255 (1956).

10. Leonard, P. J., and MacWilliam, K. M.: Cortisol binding in the serum in kwashiorkor. J. Endocrinol., 29: 273 (1964).

11. Lopez, V., Davis, S. D., ANd Smirh, N. J.: Studies in infantile marasmus. IV. Impairment of immunologic responses in the marasmic pig. Pediat. Res., 6: 779 (1972).

12. Lowry, O. H., Rosebrough, N. J., Farr, A. L., and Randall, 
R. J.: Protein measurement with the Folin phenol reagent. J. Biol. Chem., 193: 265 (1951).

13. McAnulty, P. A., and Dickerson, J. W. T.: Unpublished observations.

14. McFarlane, H., and Hamid, J.: Ccll-mediated immune response in malnutrition. Clin. Exp. Immunol., 13: 153 (1973).

15. Menzies, R. C., Crossen, P. E., Fitzgerald, P. H., and Gunz, F. W.: Cytogenetic and cytochemical studies on marrow cells in $B_{12}$ and folate deficiency. Blood, 28:581 (1966).

16. Metcalf, D.: The nature and regulation of lymphopoiesis in the normal and neoplastic thymus. In: G. E. W. Wolstenholme and R. Porter: The Thymus: Experimental and Clinical Studies, p. 242 (Ciba Foundation Symposium, Churchill, London, 1966).

17. Mugerwa, J. W.: The lymphoreticular system in kwashiorkor. J. Pathol., 105: 105 (197I).

18. Mulinos, M. G., and Pomerantz, L.: Pscudo-hypophysectomy: nutrition. J. Nutr., 19: 493 (1940).

A condition resembling hypophysectomy produced by mal-

19. Munro, H. N., AND Fleck, A.: The determination of nucleic acids. Methods of Biochem. Anal., 14: 113 (1966).

20. Rao, K. S. J., Srikantia, S. G., and Gopalan, C.: Plasma cortisol levels in protein-calorie malnutrition. Arch. Dis. Childhood, 43: 365 (1968).

21. Sainte-Marie, G., and Leblond, C. P.: Tentative pattern for the renewal of lymphocytes in cortex of the rat thymus. Proc. Soc. Exp. Biol. Med., 97: 263 (1958).

22. Sainte-Marie, G., and Leblond, C. P.: Cytologic features and ccllular migration in the cortex and medulla of thymus in the young adult rat. Blood, 23: 275 (1964).

23. Sellmeyer, E., Bhettay, E., Truswell, A. S., Meyers, O. L.,
AND HANsEn, J. D. L.: Lymphocyte transformation in malnourished children. Arch. Dis. Childhood, 47: 429 (1972).

24. SElye, H.: Studies on adaptation. Endocrinology, 21: 169 (1937).

25. Smythe, P. M., and Campbell, J. A. H.: The significance of the bacteraemia of kwashiorkor. S. Afr. Med. J., 33: 777 (1959).

26. Smythe, P. M., Schonland, M., Brereton-Stiles, G. G., Coovadia, H. M., Grace, H. J., Loening, W. E. K., Mafoyane, A., Parent, M. A., and Vos, G. H.: Thymolymphatic deficiency and depression of cell-mediated immunity in proteincalorie malnutrition. Lancet, ii: 939 (1971).

27. Svoboda, D., Grady, H., and Higginson, J.: The effects of chronic protein deficiency in rats. II. Biochemical and ultrastructural changes. Lab. Invest., 15: 731 (1966).

28. Vint, F. W.: Post-mortem findings in the natives of Kenya. E. Afr. Med. J., 13: 332 (1937).

29. Winick, M., ANd Noble, A.: Cellular response in rats during malnutrition at various ages. J. Nutr., 89: 300 (1966).

30. Oxoid Ltd., London, England.

31. The authors gratefully acknowledge the help given by Dr. J. P. G. Williams with the photomicrographs and in the preparation of this paper. They are also grateful to Professor J. M. Tanner for his encouragement and interest.

32. This research was supported by the Medical Research Council through a long term grant to Professor J. M. Tanner.

33. Requests for reprints should be addressed to: P. A. MCANulty, B.Sc., Department of Growth and Development, Institute of Child Health, 30 Guilford St., London WC1N IEH, England.

34. Accepted for publication April 8, 1973. 